\title{
Influence of grazing management on claw disorders in Swedish freestall dairies with mandatory grazing
}

\author{
C. Bergsten, ${ }^{* 1}$ J. Carlsson, $†$ and M. Jansson Mörk† \\ *Department of Biosystems and Technology, Swedish University of Agricultural Sciences (SLU), SE-230 53 Alnarp, Sweden \\ †Department of Animal Health, Växa Sverige, SE-101 24 Stockholm, Sweden
}

\begin{abstract}
Our hypothesis was that grazing time, the number of days (duration) and number of hours per day, affected claw health. From Swedish freestall herds that fulfilled our criteria of claw-trimming routines, 201 herds were randomly selected for a telephone interview regarding grazing management. Herd data were retrieved from the Swedish Official Milk Recording Scheme. Claw disorders to be analyzed were recorded at maintenance claw trimming before and after the grazing period and included mild and severe dermatitis, severe heel-horn erosion, and sole ulcer (including severe sole hemorrhage). Any remark included one or more of these recorded disorders. The odds for having a recorded claw disorder at the autumn trimming in relation to grazing management, as well as to herd- and cow-related parameters, was tested using multilevel logistic regression models. The final statistical analysis included 17,600 cows in 174 herds, which were distributed from the south to the north of Sweden with decreasing length of mandatory grazing period because of climate. Grazing duration was statistically associated with the risk of sole ulcer, but it was not linear. However, grazing duration was not statistically associated with the odds for any remark, dermatitis, or heel-horn erosion. The odds for dermatitis were lower with access to pasture for $24 \mathrm{~h}$ compared with either day or night access. Otherwise, the number of hours that the animals had access to grazing per day was not significantly associated with any of the other analyzed claw disorders. Higher pasture stocking density (number of cow hours per day per hectare) was associated with a higher odds for dermatitis and sole ulcer. For all recorded claw disorders, the highest odds for having a disorder after
\end{abstract}

Received December 14, 2014.

Accepted May 18, 2015.

${ }^{1}$ Corresponding author: christer.bergsten@slu.se the grazing period were consistently when the cow had the same claw disorder before the release to pasture. The positive effects of grazing on claw health were less than expected, and the previous known effects of breed, days in milk, parity, production system, housing environment, and management were verified for most claw disorders. If cows in today's loose housing systems have a more restrictive grazing than cows in tie-stall herds previously experienced, one cannot expect as strong an effect even if grazing is mandatory in all Swedish dairy cattle. Despite some positive effects of grazing, good stall environment and management during the housing period seem to be more important to obtain good claw health.

Key words: dairy cow, pasture, claw disorder, lameness

\section{INTRODUCTION}

Since 1988 it is legislated that all Swedish dairy cattle shall be on daily pasture for a continuous period in summer, which for dairy cows is related to climate and vegetation zone and varies from 4 mo in the very south, 3 mo in south to mid, and 2 mo in the north of Sweden (SBA, 2010). Since the law was enacted, milk production and its infrastructure have changed much, and in 2011 it was estimated that more than $60 \%$ of cows were loose housed (mainly freestalls) compared with around $20 \%$ in 1988. Moreover, from 2007 building new tie stalls was no longer allowed, and consequently, the trend toward loose housing and larger herds accelerated further (SBA, 2010). At the same time, automatic milking systems (AMS) rapidly increased, and today more than $30 \%$ of Swedish milk is produced in AMS farms.

Grazing favors the cows, in accordance with the intent of the Animal Welfare Act, and the ability to behave naturally, and depending on environmental conditions, it improves their locomotion with less lameness and better claw and leg health (Hernandez-Mendo et al., 2007; Laven and Holmes, 2008; Rutherford et 
al., 2008). Studies have also shown that modern cow houses, which meet the needs of space and optimal cow comfort, reduce the risk of lameness and claw and leg injuries as well as offer from better hygiene (Fulwider et al., 2008; Cook and Nordlund, 2009). A pasture with sufficiently large area per animal reduces infectious pressure provided that track ways are maintained and designed to the actual number of animals. However, with increased herd size, the risk exists for potential bottlenecks at the exit and entrance from the barn or milking area, which instead become contagion traps during particularly bad weather conditions (Stafford and Gregory, 2008). If the animals need to go longer distances on hardened, poorly maintained track ways, the risk of traumatic claw injuries increases (Clackson and Ward, 1991). Depending on the pasture design, number of cows per hectare, precipitation, and trackway conditions, grazing can in poor conditions mean a deterioration in the cow environment and risk of traumatic lesions. This could result in higher risk for infectious claw disorders (Bendixen et al., 1986; Alban et al., 1996). With a concrete sealing of roads and holding areas, outdoor conditions become equivalent to those indoors with requirements of comfortable, hygienic, slip-resistant surfaces, which otherwise under poor husbandry conditions can disadvantage claw health (Loberg et al., 2004).

The motivation of cows to graze when given a free choice is dependent on different factors (Charlton et al., 2013; Lyons et al., 2014). In a Canadian preference study, dairy cows in a conventional freestall system chose being out at night but to a lesser extent in rainy weather and chose to be inside during the day and to a greater extent with increased outdoor temperature and humidity (Legrand et al., 2009). A Swedish study showed that cows in AMS that were offered grazing alone during parts of the day spent more time outdoors and on pasture than cows that were offered pasture with free access to silage indoors (Andersson, 2012).

Grazed dairy heifers had better claw health than zero-grazed heifers when assessed during the grazing period (Holzhauer et al., 2012). However, in the same study no difference in claw health was seen when the same animals were compared during the housing period. Moreover, it has not been examined how much grazing is needed to achieve a long-lasting positive effect on claw health. Results from Canada (Hernandez-Mendo et al., 2007) showed that locomotion disorders or lameness improved relatively quickly when the animals came out to pasture during a 4-wk period compared with those who remained housed in freestalls bedded with sand.

The study's goal was to highlight the issue of grazing duration, how many daily hours, what part of the day the cows were grazing, and how the stocking density of cows on pasture affected claw health.

\section{MATERIALS AND METHODS}

\section{Study Population and Design}

Dairy herds enrolled in the Swedish Official Milk Recording Scheme (SOMRS) and meeting the following criteria were selected: freestall system, at least $80 \%$ of the cows in the herd were claw trimmed and claw disorders were recorded and reported during spring and autumn 2010, and that the claw trimmer of the herd should have gathered claw-trimming reports in at least 5 other herds meeting the criteria above.

Information about the study herds was retrieved from the SOMRS. The data included herd characteristics, such as herd size and milking system, as well as information of individual cows, such as breed, parity, calving date, and records of claw disorders made at maintenance claw trimming.

Information about grazing routines, pasture management, and housing (Table 1) during 2010 and 2011 were collected by telephone interviews during the summer in 2011 by 3 persons. The 269 dairy farms meeting the inclusion criteria were given a random number, and the farmers were then contacted in ascending numerical order. Of 230 owners or managers contacted, 19 declined participation and 10 wanted to be called back later but could then not be reached. A total of 201 herds participated in the telephone interview, which fulfilled the goal of 200 herds. A total of 174 herds ( $87 \%$ of those interviewed and $65 \%$ of the sample) had information on the date of release to pasture and time of housing as well as had trimmed the main part of the cows in the herd within given range for spring and autumn trimming and were included in the study. The questionnaire (in Swedish) is available from the corresponding author upon request.

\section{Claw-Disorder Records and Data Editing}

Claw disorders that were analyzed were recorded by professional claw trimmers at routine claw trimming and reported to the SOMRS. The diagnoses and scoring followed the common Nordic Claw Atlas (https:// www.landbrugsinfo.dk/kvaeg/sundhed-og-dyrevelfaerd/produktionssygdomme/klove-og-lemmer/sider/ startside.aspx) with the following diagnoses: mild and severe dermatitis [severe dermatitis is synonymous with digital dermatitis (DD)], mild and severe heel-horn erosion, mild and severe sole hemorrhage, and mild and severe sole ulcer. 
Table 1. Overview of initially analyzed explanatory variables for claw disorders at autumn trimming after pasture, divided into subject oriented groups

\begin{tabular}{|c|c|}
\hline Group & Variables \\
\hline Housing & $\begin{array}{l}\text { Housing system for heifers or dry cows (freestalls, deep straw bedding, tie stalls); freestall surface (mattress, rubber } \\
\text { mat, other); bedding material (sawdust, shavings, straw, other); amount of bedding material }\left(\mathrm{m}^{3}\right) \text {; flooring system } \\
\text { on alleys, feeding alley, or holding pen (solid scraped, slatted, combinations); flooring surface in alleys, feeding alley, } \\
\text { or holding pen (grooved concrete, smooth concrete, rubber); feed stalls (yes/no); slippery flooring (yes/no) }\end{array}$ \\
\hline Passage ways & $\begin{array}{l}\text { Length of passage way }(\mathrm{m}) \text {, durability of passage way in wet weather (good, poor), foundation just outside the barn } \\
\text { (concrete, rubber, gravel, soil, other), foundation of passage ways (gravel, rubber, soil, bark, other) }\end{array}$ \\
\hline Pasture conditions & $\begin{array}{l}\text { Pasture type (permanent cultivated, regrowth cultivated, seminatural, exercise), pasture size (hectare), soil type } \\
\text { (describe), grazing type (rotational, strip grazing, large parcel, exercise pen), days per parcel or pen if several } \\
\text { (days), different pasture conditions for dry cows or high-yielding cows (describe), water access (water bowl, water } \\
\text { trough, other), water system (permanent, mobile), access to shadow (yes/no), fertilizing (yes/no), irrigation (yes/ } \\
\text { no), trimming weed (yes/no), supplementary feeding at pasture (yes/no), proportion of roughage from pasture } \\
\text { (percent) }\end{array}$ \\
\hline Cow & $\begin{array}{l}\text { Breed (Swedish Holstein, Swedish Red, Swedish Holstein } \times \text { Swedish Red, other), calved during pasture period (yes } / \\
\text { no), claw disorders at spring trimming (yes/no), DIM at autumn trimming, dry cow during pasture period (yes } / \text { no), } \\
\text { parity (no. of lactations), suckler cow (yes/no) }\end{array}$ \\
\hline
\end{tabular}

Claw-trimming records from trimmings made from January 2010 until 15 d after the first day released on pasture were counted as spring trimming. Claw trimming records from $16 \mathrm{~d}$ on pasture until $60 \mathrm{~d}$ after housing were counted as autumn trimming in the analysis of any remark, sole ulcer, and heel-horn erosion. For dermatitis (mild and severe DD) claw trimmings from $16 \mathrm{~d}$ on pasture until $15 \mathrm{~d}$ after housing were counted as autumn trimming. A shorter interval was chosen because dermatitis will be quicker affected by a change of environment than claw horn-related disorders. The claw horn grows with a speed of 4 to $5 \mathrm{~mm}$ per month (Telezhenko et al., 2009), which will both delay the development of new claw horn lesions (Ossent and Lischer, 1998) and reduce the speed of healing in comparison with lesions of the skin (dermatitis). If a cow had more than one spring trimming, the trimming closest to the first day at pasture was counted, whereas all trimmings counted as autumn trimmings were analyzed. Days on pasture was calculated from the first day on pasture to either (a) the first day housed for cows with the autumn trimming taking place after the pasture period or (b) the day for claw trimming for cows with an autumn trimming during the pasture period. Only cows with both spring and autumn trimming records were included.

All explanatory variables collected by telephone interviews or from the SOMRS, are summarized in Table
1, divided into subject-oriented groups (herd characteristics, housing, passage ways, pasture conditions, grazing conditions, and cow) and were all analyzed. Stocking density at pasture was calculated according to Equation 1. Herds in which at least $80 \%$ of the cows were Swedish Holstein (SH) or Swedish Red (SR) breed were considered as purebred herds.

stocking at pasture $=$ (number of milking cows/daily access to pasture, h)/ha of pasture.

\section{Statistical Analysis}

Editing of data and statistical analysis was made in Stata version 10.0 (Stata Corporation, College Station, TX). The odds for having a recorded claw disease at the autumn trimming was tested using multilevel logistic regression models. Each claw disease was analyzed separately. The dependent variable was a recorded claw disease at autumn trimming (yes/no). From the recorded disorders, mild heel-horn erosions and mild sole hemorrhages were not included. The reason for this was that mild cases of heel-horn erosion and sole hemorrhage may not be recorded by all claw trimmers as well as milder cases are not considered to cause lameness and suffering for the animals. Severe sole hemorrhages were analyzed together with mild and severe sole ul- 
cers, hereafter referred to as sole ulcer, as these latter lesions are strongly correlated (Manske et al., 2002a). Sole ulcer has been the claw disease most likely causing lameness in Swedish and international studies (Manske, 2002a; Flower and Weary, 2006). Mild dermatitis and severe dermatitis were initially analyzed separately, but the model for severe dermatitis showed poor fit. Mild and severe dermatitis were therefore merged and analyzed together. The model fit was poor because cases of severe dermatitis were few and it was only present in 33 herds. Any remark included at least one of the analyzed disorders here described. Claw trimmer and herd were included as random effects because the cows were clustered within the herd and herds were clustered within the claw trimmer.

Initially all explanatory variables (presented in Table 1) were tested in univariable models (including random effects of claw trimmer and herd). Explanatory variables with a $P$-value $<0.2$ in the univariable analysis were included in the multivariable analysis. Cow- and herd-level variables considered for multivariable analyses are shown in Table 2 and Table 3, respectively. Of the explanatory variables considered for multivariable analysis, 4 had missing data: daily access to pasture was missing for 1,089 trimmings in 8 herds, pasture stocking was missing for 1,808 trimmings in 4 herds, length of passage ways was missing for 149 trimmings in 2 herds, and separate pasture for high-yielding cows was missing for 189 trimmings in one herd. The linear relationship between the dependent variable and continuous explanatory variables was tested by including the squared term of the centered explanatory variable in the models. Also, the relationship between the dichotomous dependent variable and the continuous explanatory variables was assessed visually using lowess curves with a logit function. If the relationship was nonlinear, the continuous variables were categorized. Pasture stocking, daily access to pasture, and days between spring and autumn trimmings were categorized using the 25 th, 50 th, and 75 th percentiles. Days in milk were categorized into $<70,70$ to $149.9,150$ to 289.9 , and $\geq 290$ DIM; herd size into $<50,50$ to $99.9,100$ to 199.9 , and $\geq 200$ cows; grazing duration into $<75,75$ to 99.9, 100 to $122.9,123$ to 132.9 , and $\geq 133 \mathrm{~d}$; and length of passage ways into $<50$ and $\geq 50 \mathrm{~m}$. For dermatitis, grazing period was categorized into $<100,100$ to 122.9, 123 to 132.9 , and $\geq 133 \mathrm{~d}$ due to too few herds in the lowest category. In the analysis of dermatitis only 85 herds were included, because of not fulfilling criteria of trimming interval between release to pasture and housing.

Correlations between explanatory variables considered for further analysis were investigated using Spear- man correlation coefficients. If a correlation was $\geq 0.7$ or $\leq-0.7$, one of the explanatory variables was dropped.

The full model was reduced by backward elimination until all variables remaining had a $P$-value $<0.5$. Grazing-related variables (grazing period, daily access to pasture, and days between spring and autumn trimming) were, however, retained in the model, regardless of their $P$-value. Trimming interval between spring and autumn trimming and if calving occurred during pasture were used to correct for between-herd and between-cow variation for time between trimmings and time between trimming and first day at pasture, and housing time, respectively.

Model fit was assessed through examination of plots of standardized residuals against the estimated value and the normal probability plot.

\section{RESULTS}

Table 4 shows the median of actual grazing period divided into legal grazing requirements. Almost 90\% of the herds in all pasture zones had a longer grazing period than legalized as reported from the interview. Also, $86 \%$ of the herds stated that the cows had access to pasture more than the stipulated minimum of $6 \mathrm{~h}$ a day. In $75 \%$ of the herds the barn door was kept open so that the cows could go in and out as they wanted

\section{Analysis of Claw Disorders at the Autumn Trimming}

The prevalences of claw disorders at spring trimming are presented in Table 2. At autumn trimming the prevalence of any remark was $22.6 \%$, dermatitis $14.7 \%$ ( $10.7 \%$ mild dermatitis and $4 \%$ digital dermatitis), sole ulcer $8.5 \%$ (2.9\% severe sole hemorrhage, $3.4 \%$ mild sole ulcer, and $2.2 \%$ severe sole ulcer), and severe heel-horn erosion $3.1 \%$. The models and results of the analysis of risk factors for any remark, dermatitis, sole ulcer, and heel-horn erosion at the autumn trimming are shown in Tables 5, 6, 7, and 8 .

\section{Grazing Factors}

Grazing duration was statistically associated $(P<$ $0.05)$ with the odds for sole ulcer. However, the relationship was not linear, that is, it did not decrease with the increase in the number of days on pasture. Grazing duration did not significantly relate to odds for any remark, dermatitis, or heel-horn erosion.

The number of hours per se that the animals had access to grazing expressed as hours per day was not statistically associated with the odds for any of the analyzed claw disorders. However, when expressed as 
Table 2. Distribution of cow-level explanatory variables associated with claw disorders at trimming after pasture included in the multivariable analysis

\begin{tabular}{|c|c|c|c|}
\hline Individual cow variable & Category & Number & $\%$ \\
\hline \multirow[t]{2}{*}{ Any remark, ${ }^{1}$ spring trimming } & No & 13,856 & 78.7 \\
\hline & Yes & 3,742 & 21.3 \\
\hline \multirow{2}{*}{ Dermatitis, spring trimming } & No & 15,021 & 85.4 \\
\hline & Yes & 2,577 & 14.6 \\
\hline \multirow[t]{2}{*}{ Digital dermatitis, spring trimming } & No & 17,070 & 97.0 \\
\hline & Yes & 528 & 3.0 \\
\hline \multirow[t]{2}{*}{ Sole ulcer, spring trimming } & No & 16,561 & 94.1 \\
\hline & Yes & 1,037 & 5.9 \\
\hline \multirow[t]{2}{*}{ Heel-horn erosion, spring trimming } & No & 16,985 & 96.5 \\
\hline & Yes & 613 & 3.5 \\
\hline \multirow[t]{2}{*}{ Dry cow during pasture period } & No & 12,812 & 72.8 \\
\hline & Yes & 4,786 & 27.2 \\
\hline \multirow[t]{2}{*}{ Calved during pasture period } & No & 13,446 & 76.4 \\
\hline & Yes & 4,152 & 23.6 \\
\hline \multirow[t]{2}{*}{ Suckler cow } & No & 17,487 & 99.7 \\
\hline & Yes & 51 & 0.29 \\
\hline \multirow[t]{4}{*}{ DIM at autumn trimming } & $<70$ & 2,976 & 16.9 \\
\hline & $70-149$ & 2,978 & 16.9 \\
\hline & $150-289$ & 6,743 & 38.3 \\
\hline & $\geq 290$ & 4,901 & 27.9 \\
\hline \multirow[t]{4}{*}{ Days between spring and autumn trimming } & $<140$ & 4,388 & 24.9 \\
\hline & $140-174$ & 4,373 & 24.9 \\
\hline & $175-188$ & 3,835 & 21.8 \\
\hline & $\geq 189$ & 5,002 & 28.4 \\
\hline \multirow[t]{5}{*}{ Grazing period } & $\overline{<} 75$ & 896 & 5.1 \\
\hline & $75-99$ & 3,641 & 20.7 \\
\hline & $100-122$ & 3,318 & 18.9 \\
\hline & $123-132$ & 1,560 & 8.9 \\
\hline & $>132$ & 8,183 & 46.5 \\
\hline \multirow[t]{4}{*}{ Breed } & Swedish Red & 7,350 & 41.8 \\
\hline & Holstein & 9,069 & 51.5 \\
\hline & Swedish Red $\times$ Holstein & 762 & 4.3 \\
\hline & Other & 417 & 2.4 \\
\hline \multirow[t]{4}{*}{ Parity } & $1 \mathrm{st}$ & 5,426 & 30.8 \\
\hline & 2nd & 5,940 & 33.8 \\
\hline & 3rd & 3,389 & 19.3 \\
\hline & $\geq 4 \mathrm{th}$ & 2,843 & 16.2 \\
\hline
\end{tabular}

${ }^{1}$ One or more of the recorded claw disorders.

which part of the day the cows had access to pasture, the odds for dermatitis was lower in herds with cows on pasture $24 \mathrm{~h}$ a day compared with herds where cows were out at night or where time of day varied (different groups were grazed at different times or with a variation during the grazing season).

The association between pasture stocking (number of cow-hours per day per hectare of pasture) and dermatitis and sole ulcer was statistically significant $(P=$ 0.03 and 0.02 , respectively). In herds where the pasture stocking was $>10.96$ cows per hectare, the odds for dermatitis were higher than in herds with lower stocking. The odds for sole ulcer were higher in herds with a pasture stocking of $\geq 5.04$ compared with herds with $<2.62$ cows per hectare.

\section{Herd-Related Factors}

Floor type had a statistically significant $(P=0.03$ and 0.01 , respectively) association with any remark and sole ulcer, with higher odds for cows in herds with solid, scraped alleys compared with those with slatted floors. Cows in herds with rubber mats in the alleys had a higher odds for dermatitis compared with cows on concrete floors. Organic herds had lower odds for heel-horn erosion than conventional herds.

\section{Cow-Related Factors}

The number of days between spring and autumn trimming had a statistically significant $(P=0.001$ and 0.004 , respectively) association with dermatitis and sole ulcer. The odds for dermatitis were higher for cows with 175 to 188.9 d between trimmings than for cows with $<175$ or $\geq 189 \mathrm{~d}$ between trimmings. The odds for sole ulcer were higher for cows with $\geq 189$ d between trimmings compared with cows with $<175$ d between trimmings.

The odds for a claw disorder (any remark, dermatitis, sole ulcer, and heel-horn erosion) at the autumn trim- 
Table 3. Distribution of herd-level explanatory variables associated with claw disorders at trimming after pasture included in the multivariable analysis

\begin{tabular}{|c|c|c|c|}
\hline Herd-level variable & Category & Number & $\%$ \\
\hline \multirow[t]{4}{*}{ Access to pasture (time of day) } & Day & 72 & 41.4 \\
\hline & Night & 8 & 4.6 \\
\hline & $24 / 7$ & 70 & 40.2 \\
\hline & Mixed & 24 & 13.8 \\
\hline \multirow{4}{*}{ Daily access to pasture $(\mathrm{h} / \mathrm{d})$} & $<7$ & 26 & 15.7 \\
\hline & $7-8$ & 39 & 23.5 \\
\hline & $9-17$ & 45 & 27.1 \\
\hline & $\geq 18$ & 56 & 33.7 \\
\hline \multirow{3}{*}{ Flooring system alleys } & $\overline{\text { Solid scraped }}$ & 108 & 62.1 \\
\hline & Slatted & 45 & 25.9 \\
\hline & Combinations & 21 & 12.1 \\
\hline \multirow{4}{*}{ Foundation at passage ways } & No passage ways & 25 & 14.4 \\
\hline & Gravel & 67 & 38.5 \\
\hline & Soil & 12 & 6.9 \\
\hline & Other & 70 & 40.2 \\
\hline \multirow[t]{4}{*}{ Foundation outside the barn } & Gravel & 36 & 20.7 \\
\hline & Concrete & 69 & 39.7 \\
\hline & Soil & 9 & 5.2 \\
\hline & Other & 60 & 34.5 \\
\hline \multirow[t]{4}{*}{ Herd size } & $<50$ & 8 & 4.6 \\
\hline & $50-99.9$ & 82 & 47.1 \\
\hline & $100-199.9$ & 67 & 38.5 \\
\hline & $\geq 200$ & 17 & 9.8 \\
\hline \multirow{3}{*}{ Length of passage ways } & $\leq 50 \mathrm{~m}$ & 69 & 40.1 \\
\hline & $>50 \mathrm{~m}$ & 78 & 45.4 \\
\hline & No passage ways & 25 & 14.5 \\
\hline \multirow[t]{3}{*}{ Milking system } & Automatic & 72 & 41.4 \\
\hline & Parlor or rotary & 99 & 56.9 \\
\hline & Several & 3 & 1.7 \\
\hline \multirow[t]{4}{*}{ Pasture stocking $^{1}$} & $<2.62$ & 37 & 23.3 \\
\hline & $2.62-5.03$ & 50 & 31.5 \\
\hline & $5.04-10.95$ & 43 & 27.0 \\
\hline & $>10.96$ & 29 & 18.2 \\
\hline \multirow[t]{2}{*}{ Production system } & Conventional & 151 & 86.8 \\
\hline & Organic & 23 & 13.2 \\
\hline \multirow[t]{2}{*}{ Rubber in alleys } & No & 78 & 44.8 \\
\hline & Yes (all or some alleys) & 96 & 55.2 \\
\hline \multirow[t]{2}{*}{ Separate pasture for high-yielding cows } & No & 158 & 91.3 \\
\hline & Yes & 15 & 8.7 \\
\hline
\end{tabular}

${ }^{1}$ Number of cow hours per day per hectare of pasture.

ming was significantly higher if the cow also had the same disorder at the spring trimming.

The odds for any remark was higher in cows of $\mathrm{SH}$ compared with cows of SR or mixed breeds. Also, the odds for sole ulcer were higher in cows of $\mathrm{SH}$ breed compared with cows of SR breed or other breeds and higher for $\mathrm{SH} \times \mathrm{SR}$ crossbreeds compared with cows of SR breed.

Cows had lower odds for all claw disorders in the beginning and at the end of the lactation compared with in midlactation. The odds for any remark, sole ulcer, and heel-horn erosion increased with increasing parity, and first-parity cows had the highest odds for dermatitis.

\section{DISCUSSION}

\section{Grazing Factors}

Structural change with higher milk production, increasing herd size, and with automatic milking

Table 4. Median, minimum, and maximum number of actual days on pasture divided into regions with different length of grazing requirements based on climate and vegetation zone

\begin{tabular}{llccc}
\hline $\begin{array}{l}\text { Grazing } \\
\text { requirement }\end{array}$ & Climate zone & 10th percentile & Median & 90th percentile \\
\hline 4 mo $(122 \mathrm{~d})$ & Oceanic & 113 & 133 & 163 \\
3 mo $(91 \mathrm{~d})$ & Humid continental & 92 & 133 & 153 \\
2 mo $(60 \mathrm{~d})$ & Subarctic & 72 & 92 & 128 \\
\hline
\end{tabular}


Table 5. Final model of multilevel logistic-regression analysis of associations between explanatory variables and any remark ${ }^{1}$ (yes/no) at autumn claw trimming after grazing in 2010, in 16,509 trimmings in 167 herds

\begin{tabular}{|c|c|c|c|c|}
\hline Variable & Category & OR & $95 \% \mathrm{CI}$ & $P$-value \\
\hline \multirow[t]{4}{*}{ Daily access to pasture $(\mathrm{h} / \mathrm{d})$} & $<7$ & 1 & & \multirow[t]{4}{*}{0.46} \\
\hline & $7-8$ & 0.96 & $0.64-1.44$ & \\
\hline & $9-17$ & 0.78 & $0.52-1.19$ & \\
\hline & $\geq 18$ & 0.78 & $0.52-1.17$ & \\
\hline \multirow[t]{5}{*}{ Grazing period (d) } & $<75$ & 1.78 & $1.00-3.18$ & \multirow[t]{5}{*}{0.12} \\
\hline & $75-99$ & 1.52 & $1.03-2.23$ & \\
\hline & $100-122$ & 1.37 & $0.98-1.94$ & \\
\hline & $123-132$ & 1.03 & $0.63-1.70$ & \\
\hline & $>132$ & 1 & & \\
\hline \multirow[t]{3}{*}{ Flooring systems alley } & Slatted & $1^{\mathrm{a}}$ & & \multirow[t]{3}{*}{0.03} \\
\hline & Solid scraped & $1.48^{\mathrm{b}}$ & $1.10-1.98$ & \\
\hline & Combinations & $1.33^{\mathrm{ab}}$ & $0.85-2.08$ & \\
\hline \multirow[t]{4}{*}{ Breed $^{3}$} & SR & $1^{\mathrm{a}}$ & & \multirow{4}{*}{$<0.001$} \\
\hline & $\mathrm{SH}$ & $1.64^{\mathrm{b}}$ & $1.46-1.84$ & \\
\hline & $\mathrm{SR} \times \mathrm{SH}$ & $1.30^{\mathrm{c}}$ & $1.03-1.64$ & \\
\hline & Other & $0.97^{\mathrm{ac}}$ & $0.67-1.43$ & \\
\hline \multirow[t]{4}{*}{ Days between spring and autumn trimming } & $<140$ & 1 & & \multirow[t]{4}{*}{0.21} \\
\hline & $140-174$ & 1.12 & $0.88-1.42$ & \\
\hline & $175-188$ & 1.15 & $0.87-1.52$ & \\
\hline & $\geq 189$ & 1.21 & $1.01-1.45$ & \\
\hline \multirow[t]{4}{*}{ DIM } & $\overline{<} 70$ & $1^{\mathrm{a}}$ & & \multirow[t]{4}{*}{$<0.001$} \\
\hline & $70-149$ & $2.19^{\mathrm{b}}$ & $1.89-2.53$ & \\
\hline & $150-289$ & $1.60^{\mathrm{c}}$ & $1.40-1.82$ & \\
\hline & $\geq 290$ & $0.89^{\mathrm{a}}$ & $0.77-1.03$ & \\
\hline \multirow[t]{4}{*}{ Parity } & $\overline{1}$ & $1^{\mathrm{a}}$ & & \multirow[t]{4}{*}{$<0.001$} \\
\hline & 2 & $1.07^{\mathrm{ab}}$ & $0.95-1.20$ & \\
\hline & 3 & $1.20^{\mathrm{b}}$ & $1.05-1.36$ & \\
\hline & $\geq 4$ & $1.49^{\mathrm{c}}$ & $1.30-1.71$ & \\
\hline \multirow{3}{*}{ Remarks at spring trimming } & $\bar{N}_{o}$ & 1 & & \multirow[t]{3}{*}{$<0.001$} \\
\hline & Yes & 3.82 & $3.47-4.22$ & \\
\hline & Variance & $\mathrm{SE}$ & $95 \% \mathrm{CI}$ & \\
\hline Claw trimmer & 0.58 & 0.20 & $0.30-1.14$ & \\
\hline Herd & 0.41 & 0.07 & $0.30-0.58$ & \\
\hline
\end{tabular}

${ }^{a-c}$ Parameters with different superscripts differ significantly from each other according to the $P$-value.

${ }^{1}$ Any remark included diagnosis of dermatitis, severe heel-horn erosion, sole ulcer, or severe sole hemorrhage.

${ }^{2}$ Wald tests for all variables.

${ }^{3} \mathrm{SR}=$ Swedish Red; $\mathrm{SH}=$ Swedish Holstein

systems changes the conditions for milk production and animal welfare (Stafford and Gregory, 2008). When the Swedish legislation on grazing was introduced, as a part of the Animal Welfare Act 1988, more than $80 \%$ of milk cows were tied in stalls, grazing accounted for a substantial share of the diet in summer, and grazing would also counterbalance the lack of movements of the tethered animals during the housing season. With increased production and more loose-housed cows (freestalls), the role of grazing has now changed toward more exercise grazing with most feeding controlled indoors. Although loose-housed cows are less exercised compared with grazed, they move much more than tethered cows. Our interview survey showed that the application of grazing within each legalized grazing period had great variation and that the animals on average had a considerably longer grazing period than mandatory as is shown in Table
4. Nevertheless, some herds did not reach to the statutory grazing time.

In this study we could not see that longer grazing time improved claw health in general. In most other studies, grazing is compared with zero grazing. In the Netherlands, Somers et al. (2003) found less claw disease in grazed herds compared with zero-grazed herds. In Denmark, mortality rate, which was to a great extent related to lameness, was significantly reduced in grazed herds compared with zero-grazed herds and further reduced with increasing daily number of hours on grass (Burow et al., 2011). However, although the appreciated number of hours with access to grazing did not show any association with the claw disorders analyzed in the present study, the odds for dermatitis were considerably lower in herds where the animals were grazed $24 \mathrm{~h}$ than if they were just grazed at either night or day. In contrast Holzhauer et al. (2006) found 
Table 6. Final model of multilevel logistic-regression analysis of associations between explanatory variables and mild and severe dermatitis (yes/no) at autumn claw trimming after grazing in 2010, in 8,549 trimmings in 85 herds

\begin{tabular}{|c|c|c|c|c|}
\hline Variable & Category & OR & $95 \% \mathrm{CI}$ & $P$-value \\
\hline \multirow[t]{4}{*}{ Access to pasture (time of day) } & Day & $1^{\mathrm{ac}}$ & & \multirow[t]{4}{*}{0.02} \\
\hline & Night & $5.49^{\mathrm{a}}$ & $0.78-38.53$ & \\
\hline & $24 / 7$ & $0.36^{\mathrm{c}}$ & $0.10-1.24$ & \\
\hline & Mixed & $1.58^{\mathrm{a}}$ & $0.62-4.02$ & \\
\hline \multirow[t]{4}{*}{ Daily access to pasture $(\mathrm{h} / \mathrm{d})$} & $<7$ & 1 & & \multirow[t]{4}{*}{0.61} \\
\hline & $7-8$ & 0.55 & $0.21-1.45$ & \\
\hline & $9-17$ & 0.91 & $0.34-2.45$ & \\
\hline & $>18$ & 0.98 & $0.23-4.11$ & \\
\hline \multirow[t]{4}{*}{ Grazing period $(\mathrm{d})$} & $<100$ & 2.32 & $0.94-5.73$ & \multirow[t]{4}{*}{0.16} \\
\hline & $100-122$ & 0.80 & $0.34-1.90$ & \\
\hline & $123-132$ & 0.84 & $0.28-2.53$ & \\
\hline & $>132$ & 1 & & \\
\hline \multirow[t]{4}{*}{ Pasture stocking $^{2}$} & $<2.62$ & $1^{\mathrm{a}}$ & & \multirow[t]{4}{*}{0.03} \\
\hline & $2.62-5.03$ & $1.16^{\mathrm{a}}$ & $0.47-2.82$ & \\
\hline & $5.04-10.95$ & $1.18^{\mathrm{a}}$ & $0.50-2.81$ & \\
\hline & $\geq 10.96$ & $13.48^{\mathrm{b}}$ & $2.31-78.76$ & \\
\hline \multirow{2}{*}{ Rubber in alleys } & Concrete & $1^{\mathrm{a}}$ & & \multirow[t]{2}{*}{$<0.001$} \\
\hline & Rubber mat & $2.94^{\mathrm{b}}$ & $1.47-5.86$ & \\
\hline \multirow[t]{4}{*}{ Days between spring and autumn trimming } & $<140$ & $1^{\mathrm{a}}$ & & \multirow[t]{4}{*}{0.01} \\
\hline & $140-174$ & $1.47^{\mathrm{a}}$ & $0.90-2.38$ & \\
\hline & $175-188$ & $2.97^{\mathrm{b}}$ & $1.54-5.70$ & \\
\hline & $\geq 189$ & $1.02^{\mathrm{a}}$ & $0.70-1.48$ & \\
\hline \multirow[t]{4}{*}{ DIM } & $<70$ & $1^{\mathrm{a}}$ & & \multirow[t]{4}{*}{$<0.001$} \\
\hline & $70-149$ & $1.54^{\mathrm{b}}$ & $1.16-2.07$ & \\
\hline & $150-289$ & $1.54^{\mathrm{b}}$ & $1.21-1.97$ & \\
\hline & $\geq 290$ & $0.97^{\mathrm{a}}$ & $0.74-1.27$ & \\
\hline \multirow[t]{3}{*}{ Dermatitis at spring trimming } & $\overline{\mathrm{N}}_{\mathrm{O}}$ & 1.00 & & \multirow[t]{3}{*}{$<0.001$} \\
\hline & Yes & 6.54 & $5.39-7.94$ & \\
\hline & Variance & SE & $95 \% \mathrm{CI}$ & \\
\hline Claw trimmer & 1.38 & 0.59 & $0.60-3.21$ & \\
\hline Herd & 0.91 & 0.26 & $0.51-1.60$ & \\
\hline
\end{tabular}

${ }^{\mathrm{a}-\mathrm{c}}$ Parameters with different superscripts differ significantly from each other according to the $P$-value.

${ }^{1}$ Wald tests for all variables.

${ }^{2}$ Number of cow hours per day per hectare of pasture.

a $60 \%$ higher risk for DD with more than 8-h access to pasture than those zero-grazed.

In this study the time that cows had access to pasture was analyzed and not the actual time on pasture. This is a limitation because it is not certain that all cows were using the possibility to graze. At $75 \%$ of the farms the doors were kept open, and the cows could choose to go inside. Burow et al. (2011) found that the mortality was higher in dairy cows with access to pasture compared with those that actually were moved to pasture. Moreover, Charlton et al. (2011) did not find lame cows more likely to walk to pasture as was expected, which could explain a less positive effect of pasture on cows with an initial claw disorder (Tables 5-8) in our study. Studies measuring the actual time at pasture are needed to further investigate the effect of the length of the grazing period on claw health. In AMS, where cows are supposed to walk to pasture voluntarily, cow traffic and grazing have to be further developed (Sporndly and Wredle, 2004; Lyons et al., 2014).
In herds affected with DD, exposure of manurecontaminated floors is crucial for the prevalence (Logue et al., 2005; Rodriguez Lainz et al., 1996), and therefore also the hygiene in connection with the exit and entrance of the barn is dependent for the results. Moreover, the odds for dermatitis were higher with a greater stocking density, which makes sense in that hygiene will worsen and infection pressure will be larger due to increased risk for contact with contaminated manure. Higher odds for sole ulcer with higher stocking density at pasture could be speculated to be related to longer waiting time in connection to transfer back and forth to the pasture, often on concrete flooring, because of a larger crowd per area unit.

\section{Herd-Related Factors}

Cows in organic herds had lower odds for heel-horn erosion compared with cows in herds in production systems with conventional management (Table 8). 
Table 7. Final model of multilevel logistic-regression analysis of associations between explanatory variables and sole ulcer ${ }^{1}$ (yes/no) at autumn claw trimming after grazing in 2010, in 15,790 trimmings in 160 herds

\begin{tabular}{|c|c|c|c|c|}
\hline Variable & Category & OR & $95 \%$ CI & $P$-value ${ }^{2}$ \\
\hline \multirow{4}{*}{ Daily access to pasture $(\mathrm{h} / \mathrm{d})$} & $<7$ & 1 & & \multirow[t]{4}{*}{0.11} \\
\hline & $7-8$ & 0.90 & $0.70-1.16$ & \\
\hline & $9-17$ & 0.72 & $0.54-0.95$ & \\
\hline & $\geq 18$ & 0.80 & $0.60-1.05$ & \\
\hline \multirow[t]{5}{*}{ Grazing period (d) } & $<75$ & $1.18^{\mathrm{ab}}$ & $0.83-1.68$ & \multirow[t]{5}{*}{0.002} \\
\hline & 75-99 & $0.97^{\mathrm{a}}$ & $0.74-1.26$ & \\
\hline & $100-122$ & $1.33^{\mathrm{b}}$ & $1.06-1.66$ & \\
\hline & $123-132$ & $0.65^{\mathrm{c}}$ & $0.45-0.94$ & \\
\hline & $>132$ & $1^{\mathrm{a}}$ & & \\
\hline \multirow[t]{4}{*}{ Pasture stocking ${ }^{3}$} & $<2.62$ & $1^{\mathrm{a}}$ & & \multirow[t]{4}{*}{0.02} \\
\hline & $2.62-5.03$ & $1.23^{\mathrm{ab}}$ & $0.95-1.58$ & \\
\hline & $5.04-10.95$ & $1.35^{\mathrm{b}}$ & $1.08-1.69$ & \\
\hline & $>10.96$ & $1.67^{\mathrm{b}}$ & $1.14-2.45$ & \\
\hline \multirow[t]{3}{*}{ Flooring systems alley } & Slatted & $1^{\mathrm{a}}$ & & \multirow[t]{3}{*}{0.01} \\
\hline & Solid scraped & $1.36^{\mathrm{b}}$ & $1.10-1.66$ & \\
\hline & Mixed & $1.10^{\mathrm{ab}}$ & $0.81-1.49$ & \\
\hline \multirow[t]{4}{*}{ Breed $^{4}$} & SR & $1^{\mathrm{a}}$ & & \multirow[t]{4}{*}{$<0.001$} \\
\hline & $\mathrm{SH}$ & $1.88^{\mathrm{b}}$ & $1.62-2.18$ & \\
\hline & $\mathrm{SR} \times \mathrm{SH}$ & $1.51^{\mathrm{bc}}$ & $1.11-2.07$ & \\
\hline & Other & $1.03^{\mathrm{ac}}$ & $0.64-1.64$ & \\
\hline \multirow{4}{*}{ Days between spring and autumn trimming } & $<140$ & $1^{\mathrm{a}}$ & & \multirow[t]{4}{*}{0.004} \\
\hline & $140-174$ & $0.96^{\mathrm{a}}$ & $0.77-1.21$ & \\
\hline & $175-188$ & $1.09^{\mathrm{ab}}$ & $0.84-1.41$ & \\
\hline & $\geq 189$ & $1.33^{\mathrm{b}}$ & $1.09-1.64$ & \\
\hline \multirow[t]{4}{*}{ DIM } & $<70$ & $1^{\mathrm{a}}$ & & \multirow{4}{*}{$<0.001$} \\
\hline & $70-149$ & $2.67^{\mathrm{b}}$ & $2.20-3.24$ & \\
\hline & $150-289$ & $1.67^{\mathrm{c}}$ & $1.38-2.01$ & \\
\hline & $\geq 290$ & $0.85^{\mathrm{a}}$ & $0.68-1.05$ & \\
\hline \multirow[t]{4}{*}{ Parity } & $\overline{1}$ & $1^{\mathrm{a}}$ & & \multirow[t]{4}{*}{$<0.001$} \\
\hline & 2 & $1.44^{\mathrm{b}}$ & $1.21-1.72$ & \\
\hline & 3 & $2.12^{\mathrm{c}}$ & $1.77-2.55$ & \\
\hline & $\geq 4$ & $2.94^{\mathrm{d}}$ & $2.45-3.53$ & \\
\hline \multirow[t]{3}{*}{ Sole ulcer at spring trimming } & $\bar{N}_{o}$ & 1 & & \multirow[t]{3}{*}{$<0.001$} \\
\hline & Yes & 5.07 & $4.29-6.01$ & \\
\hline & Variance & $\mathrm{SE}$ & $95 \% \mathrm{CI}$ & \\
\hline Claw trimmer & 0.22 & 0.08 & $0.11-0.46$ & \\
\hline Herd & 0.04 & 0.02 & $0.01-0.12$ & \\
\hline
\end{tabular}

${ }^{\mathrm{a}-\mathrm{d}}$ Parameters with different superscripts differ significantly from each other according to the $P$-value.

${ }^{1}$ Sole ulcer included diagnosis of sole ulcer and severe sole hemorrhage.

${ }^{2}$ Wald tests for all variables.

${ }^{3}$ Number of cow hours per day per hectare of pasture.

${ }^{4} \mathrm{SR}=$ Swedish Red; $\mathrm{SH}=$ Swedish Holstein.

Generally cows in organic herds have a less intensive diet that may reduce the risk for claw disease both directly by manure contamination of the floors and indirectly by metabolism and susceptibility for disease. Moreover, Swedish organic herds have a stronger grazing policy with a longer grazing period and a higher daily number of hours on pasture than conventional, which is beneficial for claw health (Rutherford et al., 2009). Production system could thus be expected to be correlated with grazing factors such as grazing duration and daily access to pasture. Therefore, the model for heel-horn erosion was rerun without production system. The estimates for grazing duration and daily access to pasture did, however, not change (data not shown). Similarly, in the analyses of the other claw disorders, variables related to grazing were replaced with production system. The probability for any remark was then 1.8 times higher in conventional herds compared with organic herds, and there was a tendency for higher probability of dermatitis in conventional herds $(P=$ 0.051). However, production system did not influence probability for sole ulcer (data not shown).

Flooring system is highly related to all kinds of claw lesions and lameness. Even in complete grazing systems on the southern hemisphere, dairy cows are exposed to floors and walkways of different quality and hygiene that have a significant influence on claw health (Stafford and Gregory, 2008). Therefore, it is not surprising 
Table 8. Final model of multilevel logistic-regression analysis of associations between explanatory variables and severe heel-horn erosion (yes/no) at autumn claw trimming after grazing in 2010, in 16,509 trimmings in 167 herds

\begin{tabular}{|c|c|c|c|c|}
\hline Variable & Category & OR & $95 \% \mathrm{CI}$ & $P$-value ${ }^{1}$ \\
\hline \multirow{4}{*}{ Daily access to pasture $(\mathrm{h} / \mathrm{d})$} & $<7$ & 1 & & \multirow[t]{4}{*}{0.34} \\
\hline & $7-8$ & 0.90 & $0.40-2.02$ & \\
\hline & $9-7$ & 1.05 & $0.43-2.53$ & \\
\hline & $\geq 18$ & 0.89 & $0.37-2.12$ & \\
\hline \multirow[t]{5}{*}{ Grazing period (d) } & $<75$ & 2.13 & $0.67-6.82$ & \multirow[t]{5}{*}{0.34} \\
\hline & 75-99 & 2.35 & $1.04-5.32$ & \\
\hline & $100-122$ & 1.39 & $0.66-2.94$ & \\
\hline & $123-132$ & 1.21 & $0.37-4.02$ & \\
\hline & $>132$ & 1 & & \\
\hline \multirow[t]{2}{*}{ Production system } & Conventional & $1^{\mathrm{a}}$ & & \multirow[t]{2}{*}{0.03} \\
\hline & Organic & $0.30^{\mathrm{b}}$ & $0.10-0.89$ & \\
\hline \multirow[t]{4}{*}{ DIM } & $<70$ & $1^{\mathrm{a}}$ & & \multirow[t]{4}{*}{$<0.001$} \\
\hline & $70-149$ & $2.07^{\mathrm{b}}$ & $1.49-2.88$ & \\
\hline & $150-289$ & $1.67^{\mathrm{b}}$ & $1.22-2.28$ & \\
\hline & $\geq 290$ & $1.13^{\mathrm{a}}$ & $0.80-1.58$ & \\
\hline \multirow[t]{3}{*}{ Heel-horn erosion at spring trimming } & $\bar{N}_{o}$ & $1^{\mathrm{a}}$ & & \multirow[t]{3}{*}{$<0.001$} \\
\hline & Yes, mild & $3.08^{\mathrm{b}}$ & $2.40-3.95$ & \\
\hline & Yes, severe & $9.51^{\mathrm{c}}$ & $6.84-13.22$ & \\
\hline \multirow[t]{4}{*}{ Parity } & 1 & $1^{\mathrm{a}}$ & & \multirow[t]{4}{*}{$<0.001$} \\
\hline & 2 & $1.24^{\mathrm{ab}}$ & $0.92-1.68$ & \\
\hline & 3 & $1.58^{\mathrm{b}}$ & $1.13-2.19$ & \\
\hline & $\geq 4$ & $2.44^{\mathrm{c}}$ & $1.78-3.35$ & \\
\hline \multirow{5}{*}{ Time between spring and autumn trimming } & $<140$ & 1 & & \multirow[t]{5}{*}{0.26} \\
\hline & $140-174$ & 0.74 & $0.41-1.33$ & \\
\hline & $175-188$ & 1.44 & $0.78-2.65$ & \\
\hline & $\geq 189$ & 0.95 & $0.63-1.42$ & \\
\hline & Variance & $\mathrm{SE}$ & CI & \\
\hline Claw trimmer & 1.29 & 0.60 & $0.52-3.23$ & \\
\hline Herd & 1.10 & 0.29 & $0.66-1.83$ & \\
\hline
\end{tabular}

${ }^{\mathrm{a}-\mathrm{c}}$ Parameters with different superscripts differ significantly from each other according to the $P$-value.

${ }^{1}$ Wald tests for all variables.

to find relationships with housing conditions also during the grazing period. However, the significantly higher odds for any remark and sole ulcer for cows in herds with solid, scraped alleys compared with those with slatted floors was not expected because the hardness of these floors is the same. A higher odds for dermatitis in herds with rubber mats in the alleys compared with concrete floors is more logical because cows have a longer standing time because of the more comfortable rubber flooring (Fregonesi et al., 2004; Telezhenko et al., 2007), which could result in more dirt and bacteria exposure if the floors are not dry and clean enough.

\section{Cow-Related Factors}

A longer trimming interval being a risk factor for sole ulcer, as found in our study, is consistent with Manske et al. (2002b), who also found that shorter trimming interval significantly reduced the prevalence of lameness, sole ulcer, double sole, and sole hemorrhages. It also agrees with the findings of Espejo and Endres (2007), who found that lameness prevalence was lower on farms that carried out routine claw trimming once or twice annually in addition to reactive trimming of problem cows, compared with farms that only carried out trimming when individual cows needed it. With subjective locomotion scoring, sole ulcers are most likely correlated with lameness (Flower and Weary, 2006). However, dermatitis and heel-horn erosion were less influenced by more frequent trimming in the study by Manske et al. (2002b), whereas the present study found a somewhat inconsistent association.

The highest odds for claw disorder at autumn trimming after the grazing period was related to whether the same animal had a claw disorder at spring trimming. If so, the probability for having the problem was up to 10 times greater (severe heel-horn erosion) compared with cows that were healthy at the spring trimming. Thus, it is most important that the animals be kept healthy during the housing period even if grazing could give an instant remedy of lameness compared with remaining housed (Hernandez-Mendo et al., 2007). Holzhauer et al. (2012) found a significantly higher prevalence of DD in a group of housed cows than in a group of grazed 
cows during the grazing season. A difference that was not seen when the groups of animals were both housed (September to April). Our results stand in great contrast to what was found in the 1980s when Swedish cows were mainly tied in stalls and grazing had a considerable healing effect on claw disorders detected after the housing period (Andersson and Lundström, 1981). The reason for the contradictory result is not clear. Relatively better cow comfort; that is, freestalls, may have reduced seasonal variations. Another explanation could be that poorer grazing conditions (Table 1), that is, less actual time on grass, have reduced the beneficial effect of grazing today.

The claw health of $\mathrm{SH}$ cows was inferior to that of SR, which is in accordance with Manske (2002). Furthermore, the odds for claw disorders were lowest at the beginning and at the end of lactation and increased with increasing number of parities, except for dermatitis, which is according to literature (Sogstad et al., 2005). A higher sensitivity for dermatitis in firstcalving heifers corresponds well with previous studies and experiences (Capion et al., 2009; Holzhauer et al., 2012).

\section{CONCLUSIONS}

Although neither the number of days nor the hours per day the cows were free to use the pasture seemed to influence claw disorders at autumn trimming, dermatitis was less prevalent in herds with 24 -h grazing compared with those grazing either day or night. The odds for dermatitis and sole ulcer were lower with lower stocking density at pasture. Cow-related factors, that is, trimming interval, parity, and DIM; breed; and production system affected claw health as shown in other studies. The highest odds for claw disorder at autumn trimming were if the cow had the same disorder at spring trimming, which should encourage improvements of claw health during the housing season.

\section{ACKNOWLEDGMENTS}

We thank participating farmers and Louise Winblad von Walter (Växa Sverige, Uppsala, Sweden) and Susanna Kivling, (Östansjö, Sweden) for helpful contribution in the study. Funding for the study was received from the Swedish Board of Agriculture (Jönköping), which is greatly appreciated.

\section{REFERENCES}

Alban, L., J. F. Agger, and L. G. Lawson. 1996. Lameness in tied Danish dairy cattle: The possible influence of housing systems, management, milk yield, and prior incidents of lameness. Prev. Vet. Med. 29:135-149.

Andersson, L., and K. Lundström. 1981. The influence of breed, age, body weight and season on digital diseases and hoof size in dairy cows. Zentralbl. Veterinarmed. A 28:141-151.

Andersson, S. 2012. Deltidsbete i stall med automatisk mjölkningRastbete jämfört med produktionsbete (Part-time grazing in automatic milking systems - Exercise pasture compared to production pasture, eng abstr.). Page 7. MS Thesis 363. Dept. Anim. Nutr. Manage., Swedish Univ. Agric. Sci., Uppsala.

Bendixen, P. H., B. Vilson. I. Ekesbo, and D. B. Åstrand. 1986. Disease frequencies of tied zero-grazing dairy cows and of dairy cows on pasture during summer and tied during winter. Prev. Vet. Med. 4:291-306.

Burow, E., P. T. Thomsen, J. T. Sorensen, and T. Rousing. 2011. The effect of grazing on cow mortality in Danish dairy herds. Prev. Vet. Med. 100:237-241.

Capion, N., S. M. Thamsborg, and C. Enevoldsen. 2009. Prevalence and severity of foot lesions in Danish Holstein heifers through first lactation. Vet. J. 182:50-58.

Charlton, G. L., S. M. Rutter, M. East, and L. A. Sinclair. 2011. Effects of providing total mixed rations indoors and on pasture on the behavior of lactating dairy cattle and their preference to be indoors or on pasture. J. Dairy Sci. 94:3875-3884.

Charlton, G. L., S. M. Rutter, M. East, and L. A. Sinclair. 2013 The motivation of dairy cows for access to pasture. J. Dairy Sci. 96:4387-4396.

Clackson, D. A., and W. R. Ward. 1991. Farm tracks, stockman's herding and lameness in dairy cattle. Vet. Rec. 129:511-512.

Cook, N. B., and K. V. Nordlund. 2009. The influence of the environment on dairy cow behavior, claw health and herd lameness dynamics. Vet. J. 179:360-369.

Espejo, L. A., and M. I. Endres. 2007. Herd-level risk factors for lameness in high-producing Holstein cows housed in freestall barns. J. Dairy Sci. 90:306-314.

Flower, F. C., and D. M. Weary. 2006. Effect of hoof pathologies on subjective assessments of dairy cow gait. J. Dairy Sci. 89:139-146.

Fregonesi, J. A., C. B. Tucker, D. M. Weary, F. C. Flower, and T. Vittie. 2004. Effect of rubber flooring in front of the feed bunk on the time budgets of dairy cattle. J. Dairy Sci. 87:1203-1207.

Fulwider, W. K., T. Grandin, B. E. Rollin, T. E. Engle, N. L. Dalsted, and W. D. Lamm. 2008. Survey of dairy management practices on one hundred thirteen north central and northeastern United States dairies. J. Dairy Sci. 91:1686-1692.

Hernandez-Mendo, O., M. A. G. von Keyserlingk, D. M. Veira, and D. M. Weary. 2007. Effects of pasture on lameness in dairy cows. J. Dairy Sci. 90:1209-1214.

Holzhauer, M., B. Brummelman, K. Frankena, and T. J. Lam. 2012. A longitudinal study into the effect of grazing on claw disorders in female calves and young dairy cows. Vet. J. 193:633-638.

Holzhauer, M., C. Hardenberg, C. J. Bartels, and K. Frankena. 2006. Herd- and cow-level prevalence of digital dermatitis in the Netherlands and associated risk factors. J. Dairy Sci. 89:580-588.

Laven, R. A., and C. W. Holmes. 2008. A review of the potential impact of increased use of housing on the health and welfare of dairy cattle in New Zealand. N. Z. Vet. J. 56:151-157.

Legrand, A. L., M. A. G. von Keyserlingk, and D. M. Weary. 2009. Preference and usage of pasture versus free-stall housing by lactating dairy cattle. J. Dairy Sci. 92:3651-3658.

Loberg, J., E. Telezhenko, C. Bergsten, and L. Lidfors. 2004. Behaviour and claw health in tied dairy cows with varying access to exercise in an outdoor paddock. Appl. Anim. Behav. Sci. 89:1-16.

Logue, D. N., J. E. Offer, R. A. Laven, and W. A. Ellis. 2005. Digital dermatitis - The aetiological soup. Vet. J. 170:12-13.

Lyons, N. A., K. L. Kerrisk, N. K. Dhand, V. E. Scott, and S. C. Garcia. 2014. Animal behavior and pasture depletion in a pasturebased automatic milking system. Animal 8:1506-1515.

Manske, T. 2002. Hoof lesions and lameness in Swedish dairy cattle; prevalence, risk factors, effects of claw trimming and consequences for productivity. Page 168. PhD Thesis 135. Dept. Anim. Environ. Health, Swedish Univ. Agric. Sci., Skara. 
Manske, T., J. Hultgren, and C. Bergsten. 2002a. Prevalence and interrelationships of hoof lesions and lameness in Swedish dairy cows. Prev. Vet. Med. 54:247-263.

Manske, T., J. Hultgren, and C. Bergsten. 2002b. The effect of claw trimming on the hoof health of Swedish dairy cattle. Prev. Vet. Med. 54:113-129.

Ossent, P., and C. J. Lischer. 1998. Bovine laminitis: The lesions and their pathogenesis. In Practice 20:415-427.

Rodriguez Lainz, A., D. W. Hird, T. E. Carpenter, D. H. Read, and A. R. Lainz. 1996. Case-control study of papillomatous digital dermatitis in southern California dairy farms. Prev. Vet. Med. 28:117-131.

Rutherford, K. M., F. M. Langford, M. C. Jack, L. Sherwood, A. B. Lawrence, and M. J. Haskell. 2008. Hock injury prevalence and associated risk factors on organic and nonorganic dairy farms in the United Kingdom. J. Dairy Sci. 91:2265-2274.

Rutherford, K. M., F. M. Langford, M. C. Jack, L. Sherwood, A. B Lawrence, and M. J. Haskell. 2009. Lameness prevalence and risk factors in organic and non-organic dairy herds in the United Kingdom. Vet. J. 180:95-105.

SBA. 2010. Föreskrifter och allmänna råd om djurhållning inom lantbruket. Page 12 and 16 in SJVFS. Vol. 2010:15, code of statutes. Swedish Board Agric., Jönköping.
Sogstad, A. M., T. Fjeldaas, and O. Osteras. 2005. Lameness and claw lesions of the Norwegian red dairy cattle housed in free stalls in relation to environment, parity and stage of lactation. Acta Vet. Scand. 46:203-217.

Somers, J. G. C. J., K. Frankena, E. N. Noordhuizen-Stassen, and J. H. M. Metz. 2003. Prevalence of claw disorders in Dutch dairy cows exposed to several floor systems. J. Dairy Sci. 86:2082-2093.

Sporndly, E., and E. Wredle. 2004. Automatic milking and grazing-effects of distance to pasture and level of supplements on milk yield and cow behavior. J. Dairy Sci. 87:1702-1712.

Stafford, K. and N. Gregory. 2008. Implications of intensification of pastoral animal production on animal welfare. N. Z. Vet. J. $56: 274-280$

Telezhenko, E., C. Bergsten, M. Magnusson, and C. Nilsson. 2009. Effect of different flooring systems on claw conformation of dairy cows. J. Dairy Sci. 92:2625-2633.

Telezhenko, E., L. Lidfors, and C. Bergsten. 2007. Dairy cow preferences for soft or hard flooring when standing or walking. J. Dairy Sci. 90:3716-3724 